\title{
Kombinasi Pupuk Organik dan Anorganik untuk Optimalisasi Produksi dan Kandungan Nutrisi Umbi Taka
}

\section{Organic and Inorganic Fertilizer Combinations to Optimize Production and Nutrient Content of Tacca Tuber}

\author{
Ridwan $^{1 *}$, Wardah ${ }^{1}$, dan Dini Ariani \\ ${ }^{1}$ Bidang Botani Pusat Penelitian Biologi-LIPI \\ Jl. Raya Jakarta-Bogor Km. 46 Cibinong 16911. Indonesia \\ ${ }^{2}$ Balai Pengkajian Teknologi Bahan Alam (BPTBA)-LIPI \\ J1. Jogja-Wonosari Km 31.5, Gading, Playen, Gunungkidul, Yogyakarta 55861, Indonesia
}

Diterima 27 April 2020/Disetujui 24 Juli 2020

\begin{abstract}
Tacca (Tacca leontopetaloides [L.] Kuntze) is a herbaceous plant that grows wild in coastal areas with sandy soil texture. Tacca tuber has a fairly high nutritional content, mainly carbohydrates. At present, the utilization of tacca tuber is limited due to low availability. This research aimed to obtain the fertilizer combination to enhance yield and nutrient content of tacca tuber. The research was carried out in the field using a randomized block design consisting of 6 treatments, namely without fertilizer as a control, manure only (PK), manure combined with inorganic NPK 50\% (PKA50), manure combined with NPK 100\% (PKA100), manure combined with biofertilizer and NPK 50\% (PKHA50), and manure combined with biofertilizer and NPK 100\% (PKHA100). The 100\% NPK dose is 150: 50: $150 \mathrm{~kg} \mathrm{ha}^{-1}$. Biofertilizer used was Beyonic StarTmik with a dose of $25 \mathrm{cc} \mathrm{L} L^{-1}$ of water for seedlings soaking, $250 \mathrm{~mL}$ for each plant at the age of 1 and 3 months after planting. All those treatments were replicated 5 times. The results showed that the highest yield of tacca tuber was obtained from PKHA50 treatment. Biofertilizer combined with inorganic fertilizer could increase tacca tuber production by 60-100\%, but did not affect the nutritional content. The combination of manure, biofertilizer, and NPK 50\% can be recommended to optimize tacca tuber production.
\end{abstract}

Keywords: biofertilizer, manure, NPK, yield

\section{ABSTRAK}

Taka (Tacca leontopetaloides [L.] Kuntze) adalah tumbuhan terna yang tumbuh liar di daerah pesisir pantai dengan tekstur tanah berpasir. Umbi taka memiliki kandungan gizi yang cukup tinggi terutama karbohidrat. Saat ini pemanfaatan umbi taka masih minim karena ketersediaannya yang rendah. Penelitian ini bertujuan untuk mendapatkan kombinasi pemupukan tumbuhan taka dalam rangka meningkatkan produksi umbi dan kandungan nutrisinya. Percobaan dilakukan di lapangan menggunakan rancangan acak kelompok yang terdiri atas 6 perlakuan, yaitu tanpa pupuk (kontrol), pupuk kandang saja (PK), pupuk kandang + pupuk anorganik NPK 50\% (PKA $\left.{ }_{50}\right)$, pupuk kandang + NPK 100\% (PKA 100$)$, pupuk kandang + pupuk organik hayati $(P O H)+N P K 50 \%\left(P_{1} A_{50}\right)$, dan pupuk kandang + POH + NPK 100\% (PKHA 100 ). Dosis NPK 100\% adalah 150:50:150 kg ha . $^{-1}$ POH yang digunakan adalah Beyonic StarTmik dengan dosis $25 \mathrm{cc} L^{-1}$ air untuk perendaman bibit, $250 \mathrm{ml}$ pertanaman pada umur 1 dan 3 bulan setelah tanam (BST). Seluruh perlakuan diulang sebanyak 5 kali. Hasil percobaan ini menunjukkan bahwa produksi umbi taka tertinggi adalah pada perlakuan PKHA ${ }_{50}$. Perlakuan POH yang dikombinasikan dengan pupuk NPK dapat meningkatkan produksi umbi taka sebesar 60-100\%, namun tidak berpengaruh terhadap kandungan gizinya. Kombinasi pupuk kandang, POH, dan NPK 50\% dapat direkomendasikan untuk optimalisasi produksi umbi taka.

Kata kunci: hasil, NPK, pupuk kandang, pupuk organik hayati

* Penulis untuk korespondensi. e-mail: ridwan6words@gmail.com 


\section{PENDAHULUAN}

Taka (Tacca leontopetaloides [L.] Kuntze) merupakan salah satu tumbuhan penghasil umbi yang terdapat di daerah pesisir sepanjang pantai pulau Jawa dan beberapa pulau di Indonesia (Wawo et al., 2015) dengan jenis tanah yang bervariasi. Tumbuhan ini biasanya tumbuh di bawah naungan, namun ditemukan juga di lahan-lahan terbuka. Dalam satu individu, tumbuhan ini memiliki satu sampai tiga tangkai daun (Meena dan Yadav, 2010), satu tangkai bunga, satu umbi induk, dan satu atau lebih umbi anakan (Syarif et al., 2014).

Umbi taka memiliki potensi untuk menjadi sumber karbohidrat alternatif karena kandungannya yang tinggi, yaitu sebesar 80-88\% (Vu et al., 2017). Selain itu, umbi taka juga mengandung protein, lemak, dan serat masingmasing sebesar 5.23, 0.785, dan $1.85 \%$. Kandungan nutrisi umbi taka tersebut menunjukkan bahwa nilai gizinya tidak kalah oleh beras, gandum, jagung, dan sumber-sumber karbohidrat lainnya. Beberapa daerah di Indonesia yang telah diketahui merupakan persebaran tumbuhan taka dan masyarakatnya telah memanfaatkannya antara lain di pesisir selatan pulau jawa seperti Garut Selatan (Wardah et al., 2017), Sukabumi, Gunung Kidul, Karimunjawa, Kepulauan Krakatau, Kepulauan Kangean (Syarif et al., 2014), dan Madura (Susiarti, 2012).

Aktivitas budidaya tanaman taka masih minim meskipun masyarakat telah banyak yang memanfaatkannya. Masyarakat biasanya mengambil umbi taka yang tumbuh liar di alam tanpa ada upaya untuk melestarikannya. Masyarakat enggan untuk membudidayakan tanaman ini karena umurnya yang terlalu panjang. Berdasarkan pengamatan pendahuluan secara empiris, umbi taka dengan bobot 2-3 kg per umbi biasanya dipanen dari tanaman yang sudah melalui 2 musim penghujan. Ini berarti bahwa diperlukan waktu sekitar 2 tahun untuk mendapatkan produksi umbi taka sebesar 10-15 ton ha-1. Oleh karena itu, diperlukan upaya untuk meningkatkan produksi umbi taka supaya usaha budidaya tanaman taka secara ekonomi lebih menguntungkan.

Salah satu cara untuk meningkatkan produksi tanaman adalah dengan meningkatkan kesuburan tanah melalui pemupukan. Penggunaan pupuk kimia tanpa memperhatikan pengembalian bahan organik selama ini telah menyebabkan rendahnya kandungan bahan organik tanah di hampir seluruh wilayah Indonesia sampai di bawah 2\% (Sumarno et al. 2009). Aplikasi pupuk organik yang dikombinasikan dengan pupuk anorganik secara berimbang kemungkinan bisa menjadi solusi. Qian et al. (2011) melaporkan bahwa aplikasi kombinasi pupuk organik dan anorganik selama 25 tahun dapat meningkatkan kesuburan tanah dan produksi tanaman padi di Cina Selatan. Selain itu, pupuk organik hayati $(\mathrm{POH})$ bisa menjadi alternatif untuk meningkatkan input unsur hara ke dalam tanah dan memacu pertumbuhan tanaman. Aplikasi pupuk hayati dilaporkan dapat meningkatkan pertumbuhan tanaman gandum dan mengurangi dosis pupuk anorganik karena kemampuannya dalam menisntesis hormon tumbuh dan berbagai asam organik, serta berperan juga sebagai P-solubilizer (Tahir et al., 2013).
Sudah banyak penelitian yang mengkaji pengaruh pupuk organik dan pupuk organik hayatiterhadap peningkatan produksi tanaman dengan mengurangi dosis pupuk anorganik. Antonius dan Agustiyani (2011) melaporkan bahwa pupuk organik hayati yang dikombinasikan dengan $50 \%$ dosis pupuk anorganik dapat meningkatkan produksi tanaman semangka sampai 17\%. El-Sayed et al. (2014) melaporkan bahwa pertumbuhan dan produksi umbi tanaman kentang meningkat dengan perlakuan pupuk kompos yang dikombinasikan dengan pupuk anorganik 50\% dosis. Suwandi et al. (2015) melaporkan bahwa pengurangan dosis pupuk anorganik sampai 50\% yang ditambah dengan pupuk organik hayati tidak menurunkan produksi bawang merah. Pandey et al. (2017) juga melaporkan peningkatan yang signifikan pada pertumbuhan dan hasil umbi dari tanaman Dahlia variabilis L. dengan aplikasi kombinasi pupuk hayati dan vermikompos.

Sampai saat ini, informasi tentang pemupukan tumbuhan taka untuk optimalisasi produksi umbi masih sulit ditemukan, apalagi dengan tambahan aplikasi pupuk organik hayati. Penelitian ini bertujuan untuk mendapatkan metode pemupukan tumbuhan taka dalam rangka meningkatkan produksi umbi dan kandungan nutrisinya.

\section{BAHAN DAN METODE}

Percobaan ini dilaksanakan di lahan pesisir pantai $( \pm$ $20 \mathrm{~m}$ dari bibir pantai) Desa Cikelet, Kecamatan Cikelet, Garut Selatan, Kabupaten Garut Jawa Barat, pada bulan Januari-Agustus 2016. Bibit yang digunakan adalah umbi taka terpilih berdasarkan ukuran (diameter $\pm 8 \mathrm{~cm}$ ), tampilan (sehat dan mulus), dan bobot ( $\pm 100 \mathrm{~g})$. Umbi dibibitkan di tempat yang ternaungi dan lembab sampai muncul tunas (2 bulan). Bibitkemudian ditanam pada guludan yang berukuran panjang $24 \mathrm{~m}$, lebar $0.5 \mathrm{~m}$, dan tinggi $0.3 \mathrm{~m}$ dengan jarak antar guludan $1 \mathrm{~m}$. Lubang tanam dibuat dengan diameter $30 \mathrm{~cm}$ x $30 \mathrm{~cm}$ dengan jarak $1 \mathrm{~m}$ yang ditanami 1 bibit per lubang. Dalam satu blok terdapat 138 individu tanaman, dan total populasi berjumlah 690 individu tanaman.

Percobaan ini terdiri atas 6 perlakuan dengan 5 ulangan yang dirancang dengan rancangan acak kelompok: 1) Tanpa pupuk (Kontrol); 2) Pupuk kandang (PK); 3) Kombinasi pupuk kandang dan pupuk anorganik 50\% $\left(\mathrm{PKA}_{50}\right)$; 4) Kombinasi pupuk kandang dan NPK 100\% $\left(\mathrm{PKA}_{100}\right)$; 5) Kombinasi pupuk kandang, $\mathrm{POH}$, dan pupuk anorganik 50\% (PKHA $\left.{ }_{50}\right)$; dan 6) Kombinasi pupuk kandang, POH, dan pupuk anorganik 100\% (PKHA $\left.{ }_{100}\right)$. Pupuk kandang yang digunakan adalah kotoran kambing yang dipelihara masyarakat sekitar lokasi penelitian. $\mathrm{POH}$ yang digunakan adalah Beyonic StarTmik produksi Puslit Biologi LIPI dengan kandungan mikroba pemacu tumbuh (Pseudomonas, Bacillus, Actinomycetes, Ochrobactrum, dan Azotobacter). Pupuk anorganik yang digunakan adalah pupuk tunggal (Urea, SP36, dan $\mathrm{KCl}$ ). Waktu dan dosis pemupukan disajikan pada Tabel 1 .

Pengamatan meliputi kondisi cuaca lokasi penelitian, kesuburan tanah, pertumbuhan, produksi, dan kandungan nutrisi umbi. Data cuaca didapatkan dari Balai Produksi dan Pengujian Roket Seksi Atmosfer LAPAN di Kecamatan 
Tabel 1. Waktu dan dosis perlakuan pemupukan tanaman taka

\begin{tabular}{lll}
\hline Perlakuan & \multicolumn{1}{c}{ Waktu } & \multicolumn{1}{c}{ Dosis } \\
\hline Pupuk kandang & Pada saat tanam & 10 ton ha $^{-1}$ \\
Pupuk organik hayati & Sebelum penanaman (perendaman bibit) & $25 \mathrm{cc} \mathrm{L}^{-1}$ air \\
& $\begin{array}{l}\text { Pada umur 1 bulan setelah tanam (bst), } \\
\text { dan 3 bst. }\end{array}$ & $250 \mathrm{ml}$ per tanaman (pengenceran \\
& & $25 \mathrm{cc} \mathrm{L}^{-1}$ air) \\
Pupuk anorganik* & $1 \mathrm{bst}$ & $50: 25: 50(\mathrm{~kg})$ \\
$50 \%$ dosis (Urea:SP36:KCl) & $4 \mathrm{bst}$ & $25: 0: 25(\mathrm{~kg})$ \\
& $1 \mathrm{bst}$ & $100: 50: 100(\mathrm{~kg})$ \\
$100 \%$ dosis (Urea:SP36:KCl) & $4 \mathrm{bst}$ & $50: 0: 50(\mathrm{~kg})$ \\
\hline
\end{tabular}

Keterangan: *Dosis ini merupakan modifikasi dari dosis pemupukan tanaman singkong yang digunakan oleh Yashir (2011)

Cikelet, Garut Selatan. Kesuburan tanah dilakukan dengan uji tanah lengkap di Laboratorium Ekologi Bidang Botani Puslit Biologi LIPI. Sampel tanah yang digunakan adalah tanah komposit zona perakaran dari 5 titik acak pada setiap perlakuan yang diambil setelah 3 bulan perlakuan. Pertumbuhan meliputi persentase tumbuh dan bertahan hidup, tinggi tanaman, diameter tangkai daun, dan warna daun. Pengamatan persentase tumbuh dilakukan pada umur 1 bulan setelah tanam (bst), parameter yang lain pada umur 5 bst. Pengamatan warna daun dilakukan menggunakan Bagan Warna Daun (BWD) dengan 4 gradasi warna (1-4) yang menunjukkan tingkat warna dari hijau cerah sampai dengan hijau pekat. Produksi tanaman adalah bobot basah umbi per tanaman yang diamati pada umur 8 bst. Kandungan nutrisi umbi yang diamati meliputi kadar air, kadar abu, karbohidrat, protein, dan lemak yang dianalisis di Balai Penelitian dan Teknologi Bahan Alam (BPTBA) LIPI Gunung Kidul.

\section{HASIL DAN PEMBAHASAN}

\section{Kondisi Cuaca Lokasi Penelitian}

Selama penelitian, lokasi ini memiliki suhu dan kelembaban udara rata-rata yang konstan. Persentase lama penyinaran matahari pada bulan September sebesar 71\%, lalu turun pada bulan Oktober 2015 sampai dengan bulan Mei 2016, meningkat kembali pada bulan Juni sampai Agustus
2016. Awal musim hujan dimulai pada bulan Desember 2015 kemudian hujan masih turun sampai dengan bulan Agustus 2016 (Gambar 1). Pertumbuhan taka sepertinya dipengaruhi oleh persentase lama penyinaran matahari. Taka biasanya mulai tumbuh pada bulan Oktober sampai dengan Mei/ Juni pada saat persentase lama penyinaran matahari sekitar $60 \%$, lalu mulai kering tajuk pada bulan Juni/Juli dimana persentase lama penyinaran matahari meningkat kembali mendekati 70\% (Gambar 1).

Kondisi tersebut sesuai dengan hasil penelitian Wardah dan Ariani (2014) yang menyatakan bahwa taka di Garut Selatan mulai tumbuh menjelang musim hujan pada Bulan Oktober atau Nopember. Umbi taka sepertinya mengalami pematahan dormansi pada persentase lama penyinaran matahari sekitar $60 \%$, sedangkan persentase lama penyinaran $70 \%$ atau lebih dapat mengganggu pertumbuhan taka yang menyebabkan mati tajuk dan menginduksi dormansi umbi taka. Fenomena seperti ini telah dilaporkan oleh Van Itterum (1992) bahwa waktu penyinaran yang singkat pada saat awal penanaman dapat memperpendek waktu dormansi umbi kentang. Sinar matahari memiliki peranan yang penting dalam pertumbuhan tanaman terutama sebagai energi dalam melakukan fotosintesis reaksi terang. Namun, penyinaran berlebih juga dapat menyebabkan laju fotosintesis tanaman Epimedium pseudowushanense menurun (Pan dan Guo, 2016) dan stres oksidatif yang berbahaya bagi tanaman jambu mete (Lima et al., 2018).

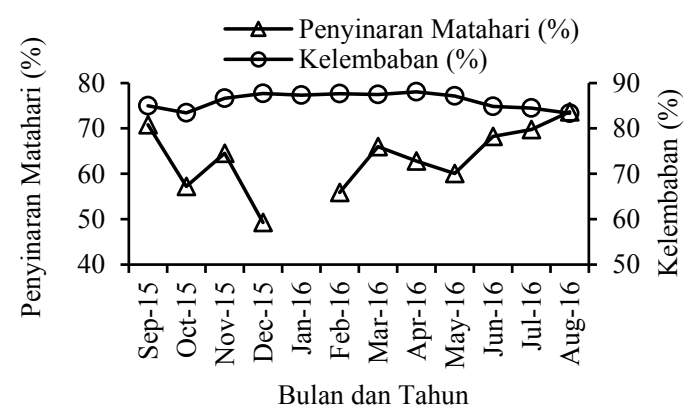

Gambar 1. Data cuaca lokasi penelitian dari bulan September 2015 sampai dengan Agustus 2016. (Sumber: Seksi Atmosfer Balai Produksi dan Pengujian Roket - LAPAN, Pameungpeuk) 


\section{Kesuburan Tanah}

Berdasarkan hasil analisis tanah lokasi penelitian dan dibandingkan dengan kriteria penilaian hasil analisis tanah dari Eviati dan Sulaiman (2009), tanah pada lahan percobaan memiliki $\mathrm{pH}$ yang netral, baik kontrol maupun yang diberi perlakuan. Kandungan C-organiknya tergolong rendah (1.30\%-1.55\%), kecuali untuk tanah yang diberi perlakuan PKHA $_{50}$ tergolong sedang (2.19\%). Kandungan $\mathrm{N}$ total tergolong sedang, sementara $\mathrm{C} / \mathrm{N}$ ratio tergolong rendah. Ketersediaan unsur hara $\mathrm{P}$ dan $\mathrm{K}$ pada tanah yang diberi perlakuan $\mathrm{POH}$ lebih tinggi dibandingkan dengan kontrol dan perlakuan tanpa POH (Tabel 2).

Tingkat kesuburan tanah dapat ditentukan berdasarkan sifat-sifat tanah, seperti kapasitas tukar kation, $\mathrm{pH}$, kandungan $\mathrm{C}$-organik, dan ketersediaan unsur hara $\mathrm{P}\left(\mathrm{P}_{2} \mathrm{O}_{5}\right)$ dan $\mathrm{K}\left(\mathrm{K}_{2} \mathrm{O}\right)$ (Alam et al., 2012). Meningkatknya kandungan C-organik tanah $(48,98 \%)$ dan ketersediaan unsur hara $\mathrm{P}$ $(78,57 \%)$ dan K $(69,97 \%)$ pada tanah yang diberi perlakuan PKHA $_{50}$ mengindikasikan terjadinya peningkatan kesuburan tanah akibat perlakuan POH. Peningkatan kesuburan tanah dengan aplikasi POH telah dilaporkan oleh Putri et al. (2018) melalui perbaikan sifat kimia dan biologi tanah. Aplikasi pupuk kandang dan $\mathrm{POH}$ dapat meningkatkan kandungan C-organik tanah dari rendah menjadi sedang karena dapat secara langsung menambah bahan organik sekaligus meningkatkan ketersediaan unsur hara di dalam tanah karena mikrob yang terkandung di dalam $\mathrm{POH}$ merupakan mikrob pengikat $\mathrm{N}$ dan pelarut $\mathrm{P}$ dan K. Azotobacter telah dilaporkan mampu memfiksasi $\mathrm{N}$ sekaligus pelarut $\mathrm{P}$ (Sahoo et al., 2014; Hindersah et al., 2017), sedangkan Bacillus, Pseudomonas, Actinomycetes, dan Ochrobactrum telah dilaporkan berfungsi sebagai perlarut P dan K. (Tahir et al., 2013; Noori dan Saud, 2012; Xu et al., 2015; Nandimath et al., 2017; Tuhuteru et al., 2019).

\section{Pertumbuhan Tanaman}

Hasil penelitian menunjukkan bahwa tanaman yang diberiperlakuan pupukkandang(tunggal maupun kombinasi) memiliki persentase tumbuh yang cenderung lebih tinggi dibandingkan dengan tanaman kontrol. Pada umur 5 bulan, tanaman yang memiliki persentase bertahan hidup lebih tinggi adalah yang diberi perlakuan $\mathrm{POH}$ (Gambar 2). Pada umur 6 bst, tanaman taka yang diberi perlakuan kombinasi PKHA $_{50}$ memiliki tangkai daun yang paling besar, sedangkan tanaman kontrol dan tanaman yang diberi perlakuan PKA $_{50}$ memiliki tangkai daun paling kecil. Meskipun tinggi, jumlah daun, dan warna daun tanaman taka secara statistik tidak berbeda nyata, namun tanaman yang diberi perlakuan PKHA $_{50}$ memiliki pertumbuhan yang cenderung lebih baik dengan tangkai daun paling gemuk, daun paling banyak dan paling hijau dibandingkan dengan yang lain (Tabel 3). Hal ini mengindikasikan bahwa penambahan pupuk organik dan $\mathrm{POH}$ dapat meningatkan pertumbuhan tanaman. Kemampuan $\mathrm{POH}$ dalam meningkatkan pertumbuhan tanaman telah disampaikan oleh $\mathrm{Xu}$ et al. (2015) pada tanaman timun dengan menggunakan mikrob Ochrobactrum sp. yang telah diketahui memiliki kemampuan dalam fiksasi $\mathrm{N}$, melarutkan $\mathrm{P}$ dan $\mathrm{K}$, menghasilkan IAA, ACC-deaminase, dan sebagai siderofor. Pengaruh $\mathrm{POH}$ dalam meningkatkan pertumbuhan tanaman juga telah dilaporkan oleh Tahir et al. (2013) pada tanaman gandum dengan menggunakan bakteri Azospirillum, Bacillus, dan Enterobacter.

\section{Produksi Tanaman}

Hasil penelitian menunjukkan produksi tanaman yang diberi perlakuan pupuk secara nyata memiliki produksi umbi yang lebih tinggi dibandingkan yang tidak diberi pupuk sama sekali (kontrol). Namun, dari seluruh kombinasi pupuk yang diberikan, perlakuan PKHA $_{50}$ memiliki produksi yang paling tinggi (Gambar 3). Hal ini berarti bahwa penggunaan $\mathrm{POH}$ dapat meningkatkan produksi umbi taka sekaligus menurunkan dosis pupuk NPK. Peningkatan produksi tanaman dengan aplikasi POH dan pengurangan dosis NPK telah dilaporkan pada tanaman cabai (Siahaan et al., 2018), tebu (Putri et al., 2018), tomat (Wijaya et al., 2015), dan kentang (Karamina dan Fikrinda, 2016). Hal ini karena pupuk organik secara langsung berfungsi sebagai tambahan

Tabel 2. Hasil analisis tanah setelah 3 bulan perlakuan pemupukan pada tanaman taka

\begin{tabular}{lccccccccc}
\hline Perlakuan & $\mathrm{pH}$ & $\begin{array}{c}\mathrm{Ca}(\mathrm{cmol} \\
\left.\mathrm{kg}^{-1}\right)\end{array}$ & $\begin{array}{c}\mathrm{Mg}(\mathrm{cmol} \\
\left.\mathrm{kg}^{-1}\right)\end{array}$ & $\begin{array}{c}\mathrm{Na}(\mathrm{cmol} \\
\left.\mathrm{kg}^{-1}\right)\end{array}$ & $\mathrm{C}(\%)$ & $\mathrm{N}(\%)$ & $\mathrm{C} / \mathrm{N}$ & $\mathrm{P}_{2} \mathrm{O}_{5} \mathrm{ppm}^{2}$ & $\begin{array}{c}\mathrm{K}_{2} \mathrm{O} \\
\mathrm{ppm}\end{array}$ \\
\hline Kontrol & 7.19 & 22.58 & 3.87 & 1.90 & 1.47 & 0.40 & 3.69 & 25.11 & 12.82 \\
PK & 7.36 & 21.62 & 4.13 & 1.11 & 1.55 & 0.42 & 3.71 & 21.00 & 6.89 \\
PKA $_{50}$ & 6.53 & 20.76 & 2.81 & 1.71 & 1.33 & 0.39 & 3.44 & 19.86 & 7.95 \\
PKA $_{100}$ & 6.60 & 22.56 & 4.03 & 1.85 & 1.47 & 0.40 & 3.71 & 17.50 & 8.96 \\
PKHA $_{50}$ & 6.54 & 26.74 & 2.70 & 1.56 & 2.19 & 0.39 & 5.56 & 44.84 & 21.79 \\
PKHA $_{100}$ & 6.67 & 20.37 & 2.39 & 1.44 & 1.30 & 0.40 & 3.28 & 44.37 & 30.16 \\
\hline
\end{tabular}

Keterangan: $\mathrm{PK}=$ pupuk kandang; PKA = kombinasi pupuk kandang dan pupuk anorganik; PKHA = kombinasi pupuk kandang, pupuk organik hayati, dan pupuk anorganik; 50 dan 100: 50\% dan 100\% dosis pupuk anorganik 


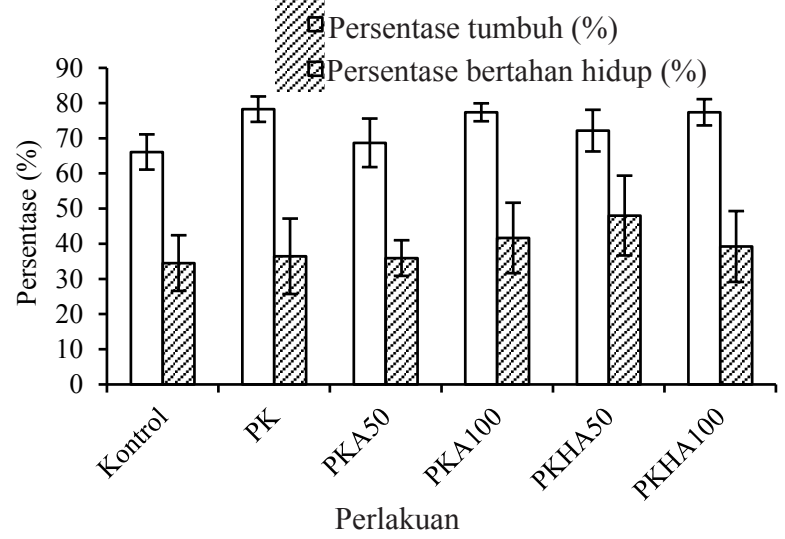

Gambar 2. Persentase tumbuh tanaman taka pada umur 1 bulan setelah tanam (bst) dan bertahan hidup sampai dengan umur 5 bst. PK = pupuk kandang; PKA = kombinasi pupuk kandang dan pupuk anorganik; PKHA = kombinasi pupuk kandang, pupuk organik hayati, dan pupuk anorganik; 50 dan 100: $50 \%$ dan $100 \%$ dosis pupuk anorganik

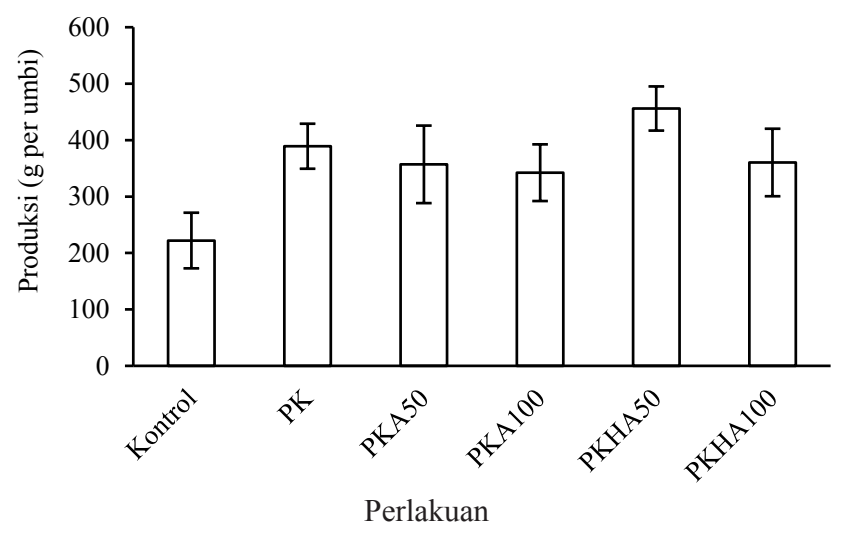

Gambar 3. Data produksi taka pada umur 8 bulan setelah tanam (bst). PK: pupuk kandang; PKA = kombinasi pupuk kandang dan pupuk anorganik; PKHA = kombinasi pupuk kandang, pupuk organik hayati, dan pupuk anorganik; 50 dan 100: 50\% dan 100\% dosis pupuk anorganik

Tabel 3. Pertumbuhan tanaman taka pada umur 6 bulan setelah tanam

\begin{tabular}{llcccc}
\hline No & Perlakuan & $\begin{array}{c}\text { Tinggi } \\
(\mathrm{cm})\end{array}$ & $\begin{array}{c}\text { Diameter tangkai } \\
\text { daun }(\mathrm{mm})\end{array}$ & $\begin{array}{c}\text { Jumlah daun } \\
\text { (helai) }\end{array}$ & Warna daun \\
\hline 1 & Kontrol & $52.36 \pm 4.40$ & $4.10 \pm 0.70 \mathrm{~b}$ & $2.85 \pm 0.39$ & $2.60 \pm 0.38$ \\
2 & $\mathrm{PK}$ & $52.60 \pm 6.87$ & $5.23 \pm 0.82 \mathrm{ab}$ & $3.95 \pm 1.03$ & $2.70 \pm 0.26$ \\
3 & $\mathrm{PKA}_{50}$ & $50.87 \pm 2.60$ & $4.27 \pm 0.31 \mathrm{~b}$ & $3.30 \pm 0.72$ & $3.02 \pm 0.33$ \\
4 & $\mathrm{PKA}_{100}$ & $58.75 \pm 5.64$ & $5.52 \pm 0.44 \mathrm{ab}$ & $3.30 \pm 0.37$ & $3.15 \pm 0.27$ \\
5 & PKHA $_{50}$ & $57.32 \pm 7.42$ & $8.39 \pm 0.83 \mathrm{a}$ & $5.29 \pm 1.41$ & $3.11 \pm 0.28$ \\
6 & PKHA $_{100}$ & $54.41 \pm 3.06$ & $4.83 \pm 0.42 \mathrm{ab}$ & $3.70 \pm 0.76$ & $3.07 \pm 0.21$ \\
\hline
\end{tabular}

Keterangan: $\mathrm{PK}=$ pupuk kandang; $\mathrm{PKA}=$ kombinasi pupuk kandang dan pupuk anorganik; $\mathrm{PKHA}=$ kombinasi pupuk kandang, pupuk organik hayati, dan pupuk anorganik; 50 dan 100: 50\% dan 100\% dosis pupuk anorganik. Data merupakan rata-rata \pm standar error dari 5 ulangan. Angka yang diikuti oleh huruf yang berbeda pada kolom yang sama menunjukkan perbedaan yang nyata berdasarkan DMRT pada taraf $\alpha=5 \%$

unsur hara di dalam tanah atau melalui peranannya dalam perbaikan struktur dan sifat-sifat tanah. Selain itu, mikrob pemacu tumbuh (plant growth promoting bacteria) yang dikandung oleh $\mathrm{POH}$ telah banyak dilaporkan juga dapat mensintesis hormon-hormon tumbuh seperti IAA dan $\mathrm{GA}_{3}$ yang dapat memacu pertumbuhan dan produksi tanaman (Tahir et al., 2013; Sahoo et al., 2014; Noori dan Saud, 2012; Xu et al., 2015; Nandimath et al., 2017). Peranan dari pupuk organik dan $\mathrm{POH}$ tersebut diduga menyebabkan pengurangan dosis pupuk anorganik sebanyak 50\% tidak menurunkan pertumbuhan dan produksi umbi taka, bahkan cenderung meningkat. Penurunan pertumbuhan dan produksi taka pada perlakuan PKHA $_{100}$ kemungkinan disebabkan oleh berlebihnya unsur hara makro yang berakibat pada menurunnya aktivitas mikrob dari $\mathrm{POH}$ yang diberikan. Hasil penelitian yang serupa telah dilaporkan pada pada tanaman bawang merah (Siagian et al., 2019).

\section{Kandungan Nutrisi}

Hasil analisis proksimat menunjukkan bahwa kandungan nutrisi tepung pati umbi taka pada semua perlakuan tidak berbeda nyata (Tabel 4), kecuali kandungan proteinnya. Umbi taka yang mengandung protein tertinggi adalah umbi tanaman yang diberi perlakuan PKA $_{100}$. Hal ini berarti bahwa kandungan protein umbi taka meningkat dengan penggunaan kombinasi pupuk kandang dan pupuk anorganik. Senyawa protein merupakan senyawa organik komplek yang banyak mengandung nitrogen. Pemupukan dengan unsur hara $\mathrm{N}$ akan berpengaruh terhadap peningkatan kandungan protein umbi tanaman. Hasil penelitian ini tidak sesuai dengan hasil penelitian Parman (2007) yang melaporkan bahwa kandungan protein tanaman Alfalfa meningkat dengan aplikasi pupuk hayati yang mengandung mikrob Rhizobium yang mampu memfiksasi N langsung dari atmosfer. 
Tabel 4. Hasil analisa proksimat tepung pati umbi taka pada umur 5 bulan setelah tanam

\begin{tabular}{lccccc}
\hline Perlakuan & Kadar abu (\%) & Air (\%) & Karbohidrat (\%) & Protein (\%) & Lemak (\%) \\
\hline Kontrol & $2.74 \pm 0.07$ & $6.81 \pm 0.01$ & $83.53 \pm 0.06$ & $6.34 \pm 0.10 \mathrm{~cd}$ & $0.58 \pm 0.04$ \\
PK & $2.56 \pm 0.02$ & $5.79 \pm 0.05$ & $84.16 \pm 0.08$ & $6.97 \pm 0.03 \mathrm{~b}$ & $0.53 \pm 0.02$ \\
PKA $_{50}$ & $2.23 \pm 0.11$ & $6.01 \pm 0.08$ & $83.87 \pm 0.05$ & $7.32 \pm 0.05 \mathrm{ab}$ & $0.58 \pm 0.02$ \\
PKA $_{100}$ & $2.46 \pm 0.05$ & $5.86 \pm 0.13$ & $83.72 \pm 0.09$ & $7.44 \pm 0.44 \mathrm{a}$ & $0.51 \pm 0.01$ \\
PKHA $_{50}$ & $2.66 \pm 0.09$ & $6.64 \pm 0.17$ & $84.03 \pm 0.13$ & $6.07 \pm 0.06 \mathrm{~d}$ & $0.60 \pm 0.02$ \\
PKHA $_{100}$ & $2.57 \pm 0.06$ & $6.91 \pm 0.28$ & $83.34 \pm 0.33$ & $6.58 \pm 0.14 \mathrm{c}$ & $0.60 \pm 0.02$ \\
\hline
\end{tabular}

Keterangan: $\mathrm{PK}=$ pupuk kandang; PKA = kombinasi pupuk kandang, Pupuk anorganik; $\mathrm{PKH}=$ kombinasi pupuk kandang, pupuk organik hayati, dan pupuk anorganik; 50 dan 100: 50\% dan 100\% dosis pupuk anorganik. Data merupakan rata-rata \pm standar error dari 5 ulangan. Angka yang diikuti oleh huruf yang berbeda pada kolom yang sama menunjukkan perbedaan yang nyata berdasarkan DMRT pada taraf $\alpha=5 \%$

\section{KESIMPULAN}

Kombinasi pupuk kandang, pupuk organik hayati, dan pupuk anorganik dapat meningkatkan persentase bertahan hidup, diameter batang tanaman, dan produksi umbi taka. Reduksi pupuk anorganik sebesar 50\% dosis yang dikombinasikan pupuk kandang dan pupuk organik hayati dapat mengoptimalkan pertumbuhan dan produksi umbi taka. Kandungan protein umbi taka meningkat pada perlakuan kombinasi pupuk kandang dan pupuk anorganik.

\section{UCAPAN TERIMA KASIH}

Penelitian ini didanai oleh Program Penelitian Unggulan Lembaga Ilmu Pengetahuan Indonesia (LIPI) tahun anggaran 2016. Ucapan terima kasih disampaikan kepada Dr. Rer.nat. Sarjiya Antonius dan tim yang telah mendukung penelitian ini dengan penyediaan pupuk organik hayati LIPI, Kepala dan petugas Balai Produksi dan Pengujian Roket Seksi Atmosfer LAPAN di Kecamatan Cikelet, Garut Selatan, serta Ir. Mukhamad Angwar, M.Sc dan Laela Fitria, SP atas bantuan teknisnya selama penelitian.

\section{DAFTAR PUSTAKA}

Alam, S., B.H. Sunarminto, S.A. Siradz. 2012. Karakteristik kesuburan tanah pada kondisi iklim berbeda di Sulawesi Tenggara. AGRIPLUS. 22:77-84.

Antonius, S., D. Agustiyani. 2011. Pengaruh pupuk organik hayati yang mengandung mikrob bermanfaat terhadap pertumbuhan dan hasil panen tanaman semangka serta sifat biokimia tanahnya pada percobaan lapangan di Malinau-Kalimantan Timur. Berk. Penel. Hayati. 16:203-206.

El-Sayed, S.F., H.A. Hassan, M.M. El-Mogy. 2014. Impact of bio- and organic fertilizers on potato yield, quality and tuber weight loss after harvest. Potato Res. 58:67-81.
Eviati, Sulaeman. 2009. Analisis Kimia Tanah, Tanaman, Air, dan Pupuk. Petunjuk Teknis Edisi 2. Balai Penelitian Tanah. Balai Besar Litbang Sumber Daya Lahan Pertanian. Badan Penelitian dan Pengembangan Pertanian. Departemen Pertanian, Bogor, ID.

Hindersah, R., N. Rostini, A. Harsono, Nuryani. 2017. Peningkatan populasi, pertumbuhan dan serapan nitrogen tanaman kedelai dengan pemberian Azotobacter penghasil eksopolisakarida. J. Agron. Indonesia 45:30-35.

Karamina, H., W. Fikrinda. 2016. Aplikasi pupuk organik cair pada tanaman kentang varietas granola di dataran medium. J. Kultiv. 15:154-158.

Lima, C.S., S.L. Ferreira-Silva, F.E.L. Carvalho, M.C.L. Neto, R.M. Aragão, E.N. Silva, R.M.J. Sousa, J.A.G Silveira. 2018. Antioxidant protection and PSII regulation mitigate photo-oxidative stress induced by drought followed by high light in cashew plants. Environ. Exp. Bot. 149:59-69.

Meena, K.L., B.L. Yadav. 2010. Tacca leontopetaloides (Linn.) O. Kuntze (Taccaceae) - A new record to the flora of Rajasthan. Indian J. Natur. Prod. Res. 1:512514.

Nandimath, A.P., D.D. Karad, S.G. Gupta, A.S. Kharat. 2017. Consortium inoculum of five thermotolerant phosphate solubilizing Actinomycetes for multipurpose biofertilizer preparation. Iran. J. Microbiol. 9:295-304.

Noori, M.S.S., H.M. Saud. 2012. Potential plant growthpromoting activity of Pseudomonas sp isolated from paddy soil in Malaysia as biocontrol agent. Plant Pathol. Microbiol. 3:1-4. Doi:10.4172/21577471.1000120 . 
Pan, J., B. Guo. 2016. Effects of light intensity on the growth, photosynthetic characteristics, and flavonoid content of Epimedium pseudowushanense B.L.Guo. Mol. 21:1-12.

Pandey, S.K., S. Kumari, D. Singh, V.K. Singh, V.M. Prasad. 2017. Effect of biofertilizer and organic manures on plant growth, flowering and tuber production of Dahlia (Dahlia variabilis L.) Cv. S.P. Kamala. Int. J. Pure App. Biosci. 5:549-555.

Parman, S. 2007. Kandungan protein dan abu tanaman Alfalfa (Medicago sativa L) setelah pemupukan Biorisa. BIOMA 9:38-44.

Putri, I.K., Z. Kusuma, S. Prijono. 2018. Aplikasi pupuk hayati majemuk cair pada tanaman tebu di PT Perkebunan Nusantara X Kediri. J. Tanah Sumber Daya Lahan 5:681-688.

Qian, H.H., L.X. Mei, L.G. Rong, L.Z. Zhang, L.Y. Ren, H.Y. Lan, J.J. Hua, S.C. Hong, W.F. Quan. 2011. Effect of long-term located organic-inorganic fertilizer application on rice yield and soil fertility in red soil area of China. Sci. Agri. Sin. 44:516-523.

Sahoo, R.K., M.W.Ansari, T.K.Dangar,S.Mohanty, N. Tuteja. 2014. Phenotypic and molecular characterisation of efficient nitrogen-fixing Azotobacter strains from rice fields for crop improvement. Protoplasma. 251: 511-523.

Siagian, T.V., F. Hidayat, S.Y. Tyasmoro. 2019. Pengaruh pemberian dosis pupuk NPK dan hayati terhadap pertumbuhan dan hasil tanaman Bawang Merah (Allium ascalonium L.). J. Prod. Tan. 7:2151-2160.

Siahaan, C.D., Sitawati, S. Heddy. 2018. Uji efektivitas pupuk hayati pada tanaman Cabai Rawit (Capsicum frutescens L.). J. Prod. Tan. 6:2053-2061.

Sumarno, U.G. Kartasasmita, Dj. Pasaribu. 2009. Pengayaan kandungan bahan organik tanah mendukung keberlanjutan sistem produksi padi sawah. Iptek Tan. Pangan. 4:18-32.

Susiarti, S., N. Setyowati, Rugayah. 2012. Etnobotani Tacca leontopetaloides (L.) O. Kuntze sebagai bahan pangan di Pulau Madura dan sekitarnya, Jawa Timur. Pangan. 21:161-170.

Suwandi, G.A. Sopha, M.P. Yufdy. 2015. Efektivitas pengelolaan pupuk organik, NPK, dan pupuk hayati terhadap pertumbuhan dan hasil bawang merah. J. Hort. 25:208-221.

Syarif, F., P. Lestari, A.H. Wawo. 2014. Variasi karakteristik pertumbuhan Tacca leontopetaloides (L) Kuntze
(Taccaceae) di pulau Jawa dan pulau-pulau kecil sekitarnya. Berita Biol. 13:161-171.

Tahir, M., M.S. Mirza, A. Zaheer, M.R. Dimitrov, H. Smidt, S. Hameed. 2013. Isolation and identification of phosphate solubilizer Azospirillum, Bacillus and Enterobacter strains by $16 S r R N A$ sequence analysis and their effect on growth of wheat (Triticum aestivum L.). AJCS. 7:1284-1292.

Tuhuteru, S., E. Sulistyaningsih, A. Wibowo. 2019. Aplikasi plant growth promoting rhizobacteria dalam meningkatkan produktivitas bawang merah di lahan pasir pantai. J. Agron. Indonesia 47:53-60.

Van Ittarum M.K. 1992. Relation between growth conditions and dormancy of seed potatoes. 3. Effects of light. Potato Res. 35:377-387.

Vu, Q.T.H., P.T.K. Le, H.P.H. Vo, T.T. Nguyen, T.K.M. Nguyen. 2017. Characteristics of Tacca leontopetaloides L. Kuntze collected from an Giang in Vietnam. AIP Conf. Proc. 1878, 020022-1-0200226; doi: 10.1063/1.5000190.

Wardah, D. Ariani. 2014. Wild Tuberof jalawure (Tacca leontopetaloides) is an alternative to overcome food insufficiency of society in Cikelet Subdistrict, South Garut. Dalam S.N Prijono, A. Agusta, A. Triyono, Purwanto, T Fizzanty, Yopi, K. Kanazawa, Z. Jiang $(E d s$.). Proceedings the 5Th ASIAHORCs International Symposium. Bali, Indonesia, 26-28 November 2013. LIPI Press.

Wardah, E.N. Sambas, Ridwan, D. Ariani. 2017. Starch product of wild plants species Jalawure (Tacca leontopetaloides L. Kuntze) as the source of food security in the coastal West Java. IOP Conf. Series: Material Science and Engineering 193 (2017) 012035. Doi:10.1088/1757-899X/193/I/o12035.

Wawo, A.H., P. Lestari, N.W. Utami. 2015. Studi perbanyakan vegetatif tanaman Taka (Tacca leontopetaloides (L.) Kuntze) dan pola pertumbuhannya. Berita Biol. 14:19.

Wijaya, A.S., M.N. Sangadji, Muhardi. 2015. Produksi dan kualitas produksi buah tomat yang diberi berbagai konsentrasi pupuk organik cair. E-J. Agrotekbis 3: 689-696.

Xu, S., L. Ying, J. Wang, T. Yin, Y. Han, X. Wang, Z. Huang. 2015. Isolation and potential of Ochrobactrum sp. NW-3 to increase the growth of cucumber. Int. J. Agric. Polic. Res. 3:341-350.

Yashir Y.E. 2011. Teknik Budidaya Singkong Mekarmanik Teknologi MiG-PLUS. CV. Tani Sukses Sejahtera. Bandung. ID. 